\title{
Seismically detected porous Zechstein carbonates in Southern Jutland, Denmark
}

\author{
KIM GUNN MAVER
}

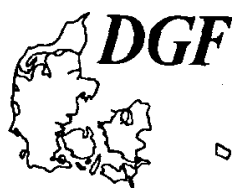

\begin{abstract}
Maver, K. G.: Seismically detected porous Zechstein carbonates in Southern Jutland, Denmark. Bulletin of the Geological Society of Denmark. Vol. 42, pp. 34-46. Copenhagen 1995-10-31. https://doi.org/1037570/bgsd-1995-42-04

Zechstein carbonates in Southern Jutland, Denmark, have been explored by 10 wells since 1952 , and a total of more than $2000 \mathrm{~km}$ of 2D seismic data has been acquired by various contractors. Seismic modelling, based on all the well data, is used as an aid to predict the lateral distribution of porous Zechstein carbonate intervals from the seismic data.

1D seismic modelling is used to define the maximum number of intervals detected by the seismic sections at well locations. The 1D seismic modelling results are also used to derive $2 \mathrm{D}$ acoustic impedance models and corresponding synthetic seismograms. The seismic modelling results illustrate a number of diagnostic reflection patterns associated with the porous carbonate intervals. The predicted distribution of porous carbonate intervals is, however, found to be uncertain, as thickness and porosity variations of each interval cannot be distinguished. Furthermore, thin porous carbonate intervals are not detected by the seismic sections, and the seismic reflection patterns indicating the presence of porous carbonate intervals can be associated with other lithologies.

Porous $\mathrm{Ca}-1 \mathrm{a}, \mathrm{Ca}-\mathrm{lb}, \mathrm{Ca}-2$ and $\mathrm{Ca}-3$ carbonate intervals are found to be detected by the seismic sections only in the Zechstein platform area, and only the porous $\mathrm{Ca}-2$ carbonate interval can be mapped.
\end{abstract}

Kim Gunn Maver, Geological Survey of Denmark, Thoravej 8, DK-2400 Copenhagen NV, Denmark 1994. Present address: ØD-S Holding A/S, Kroghsgade 1, DK-2100 Copenhagen $\emptyset$, Denmark. 23rd December 1994.

\section{Introduction}

Porous Zechstein carbonate deposits of the Southem Zechstein Basin have for many years been the target of intense investigation, which has resulted in commercial hydrocarbon production in Great Britain, the Netherlands, Germany and Poland (Clark 1986; Maureau \& van Wijhe 1979; Mathisen \& Budny 1990; Antonowicz \& Knieszner 1984). The present study focuses on the Danish part of the Southern Zechstein Basin situated in Southem Jutland using a database consisting of 10 wells (excluding the confidential Løgumkloster-2a/b well drilled in $19931.1 \mathrm{~km}$ southsouthwest of the Løgumkloster-1 well), and more than $2000 \mathrm{~km}$ of 2D seismic data acquired by various contractors (Fig. 1). Hydrocarbon indications were encountered, but all wells were plugged and abandoned (Stemmerik, Frykman, Christensen \& Stentoft 1987). Recent interpretations of the Southern Jutland Zechstein carbonate layers and porosity distribution are based mostly on well derived data (Sorgenfrei \& Buch 1964; Clark \& Tallbacka 1980; Thomsen, Damtofte \& Andersen 1987; Stemmerik et al. 1987; Stemmerik \& Frykman 1989; Frykman, Stentoft, Rasmussen, Christensen, Andersen \&
Jacobsen 1992). The large 2D seismic database has only to a small extent been included and the wells Kværs-1 and Borg-1 have not been included in previously published papers to describe the carbonate porosity distribution.

The present distribution of carbonate porosity in Southem Jutland is the result of a complex diagenetic history (Stemmerik et al. 1987). Hence, the prediction of the lateral porosity distribution from well derived data and depositional models alone is difficult as recognised by Maureau \& van Wijhe (1979) for the Netherlands. Seismic data can, however, be used to predict the lateral distribution of the porous carbonate intervals, as the acoustic impedance often is lower than the acoustic impedance of the surrounding anhydrite and more dense carbonate layers and thus results in diagnostic reflection patterns (Maver 1995b; Maver, Rasmussen, Pedersen \& Skjellerup 1994). Due to the limited variation in velocity and density of each lithology and to the cyclicity of the Zechstein deposits (Maver, Møller \& Andersen 1992), it is furthermore possible to define simple subsurface models by seismic modelling which illustrate the resolution of porous carbonate intervals. 


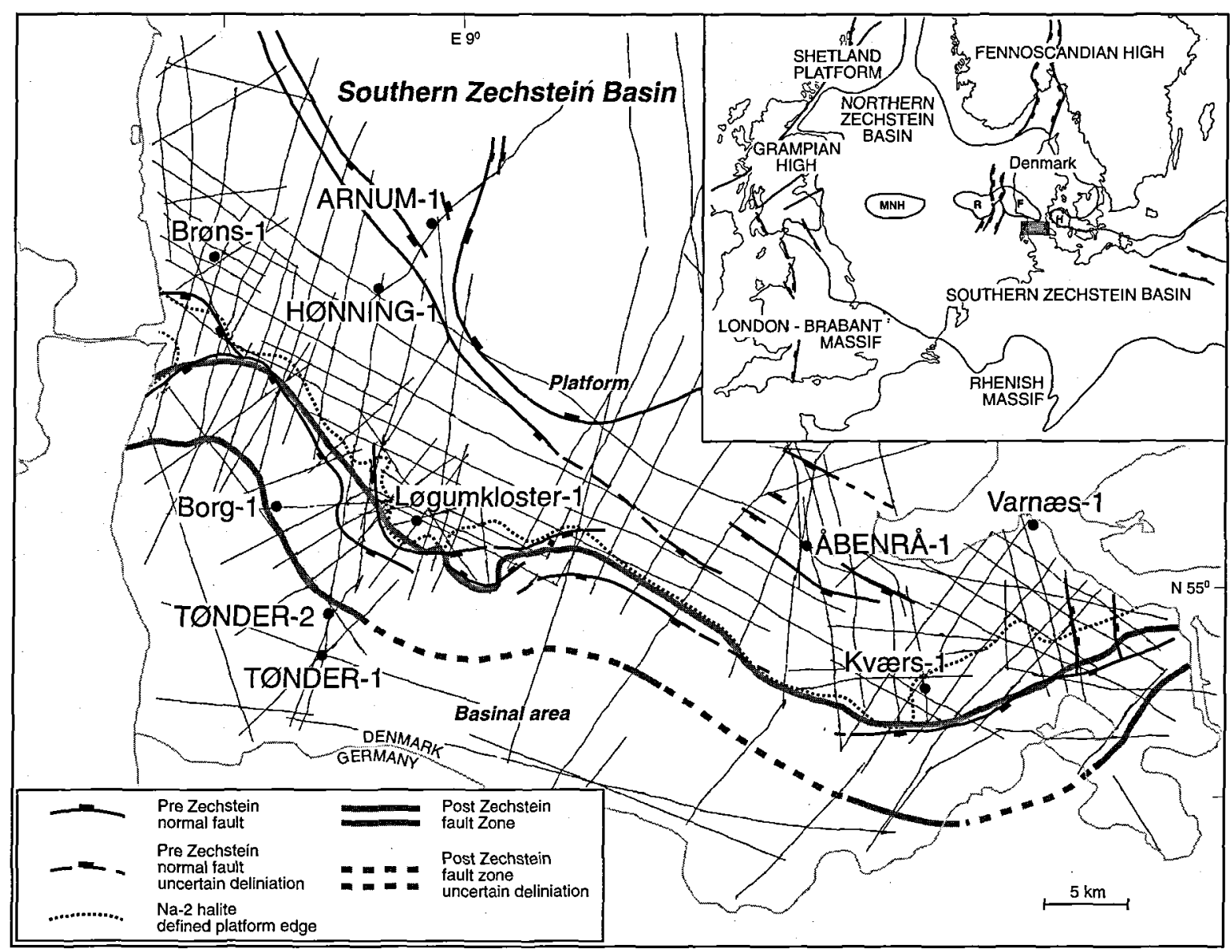

Fig. 1. Southern Jutland, Denmark with the platform edge defined by a substantially increasing Na-2 halite layer thickness. For wells indicated with capital letters neither sonic nor density logs were recorded originally. Thin lines represent seismic sections. Only major faults influencing the base Zechstein boundary are mapped. The fault zone has been active in Post Zechstein times and delineates a zone from which it is difficult to derive stratigraphic information. Insert map indicates location of area (Based on Ziegler 1981). RFH: Ringkøbing-Fyn High. MNH: Mid North Sea High.

To predict the lateral distribution of porous Zechstein carbonate intervals in Southern Jutland all data available is used. This comprises more than $2000 \mathrm{~km}$ of $2 \mathrm{D}$ seismic data and all well data, including 5 older wells drilled in the 1950's with no sonic and density logs. Only the wells Kværs-1, Løgumkloster-1, Tønder-2, Varnæs-1 and Åbenrå-1 are displayed in this paper, as these wells contribute the most information regarding the porous carbonate intervals (Fig. 1).

\section{Geological setting}

The Danish Zechstein depositional setting is described only briefly, as this has already been done thoroughly by Clark \& Tallbacka (1980), Stemmerik et al. (1987) and Stemmerik \& Frykman (1989).

In Northwestern Europe Zechstein evaporite and carbonate deposits occupy two east-west trending sub- basins partly separated by the Mid North Sea High and Ringkøbing-Fyn High (Ziegler 1981; Fig. 1). Halite predominates in each basin centre, while the shelf area along the margin of the basin was dominated by deposition of shallow water carbonates and anhydrite forming a platform.

During deposition of the Zechstein Group in Upper Permian, Southern Jutland was situated along the southern slope of the Ringkøbing-Fyn High, which formed the northern margin of the Southern Zechstein Basin (Fig. 1). Southern Jutland is divided into a northern carbonate and anhydrite dominated platform area and a southern halite dominated basinal area. The Danish Zechstein deposits consist of 5 cycles designated from Z-1 at the base to Z-5 at the top. The first three Zechstein cycles in Southern Jutland correlate with the cycles in the rest of the Southern Zechstein Basin, and include the four main carbonate layers, $\mathrm{Ca}$ 1a, Ca-1b, Ca-2 and Ca-3, whereas the Z-4 and Z-5 


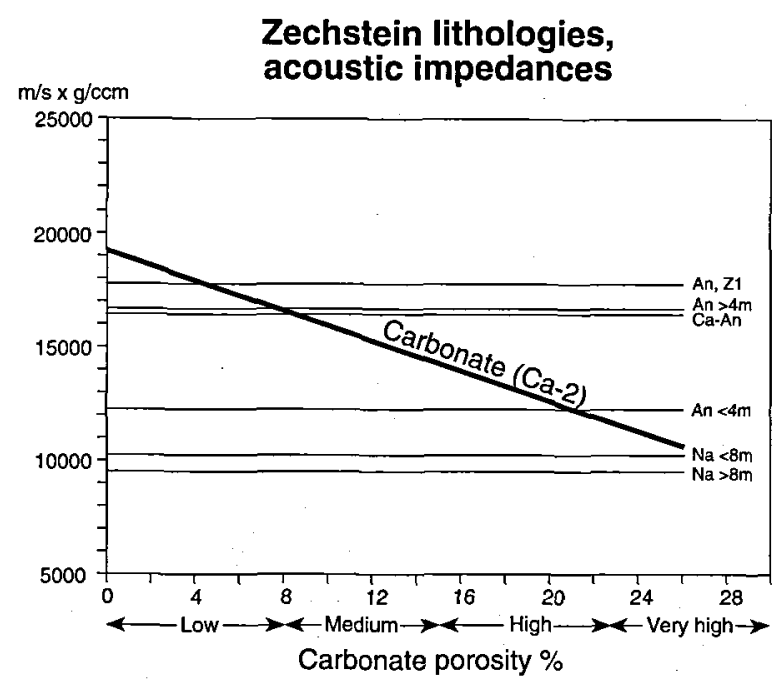

Fig. 2. The porosity versus acoustic impedance for carbonate deposits with calculated average acoustic impedances from other Zechstein lithologies. Na; Halite, An; Anhydrite, Ca; Carbonate (Adapted from Frykman et al. 1992; Maver 1995a).

cycles are only partially developed (Clark \& Tallbacka 1980; Stemmerik \& Frykman 1989). A complete evaporite cycle consists, from bottom to top, of a succession of clastic sediments, carbonate, anhydrite, halite and finally highly soluble potassium and magnesium salts, but overall carbonate $(\mathrm{Ca})$, anhydrite $(A n)$ and halite $(\mathrm{Na})$ predominate. The Zechstein cyclic development does not fully conform to this, as many omissions and stage reversals are present as has been described for instance for the British part of the Southern Zechstein Basin (Jenyon \& Taylor 1983; Jenyon \& Cresswell 1987). Anhydrite layers are often deposited out of sequence, and carbonate may later have been altered to anhydrite by diagenetic processes. Within the carbonate layers all of the dolomitic limestone is secondary in origin in Southern Jutland (Clark \& Tallbacka 1980).

The part of the $\mathrm{Ca}-2$ carbonate layer consisting of oolite shoal deposits has formed the main exploration target in Southern Jutland. $14 \mathrm{~m}$ of oolite shoal facies Ca-2 carbonate with an average porosity of $20 \%$ was encountered in the Løgumkloster-1 well (Stentoft 1990; Fig. 1).

Average velocities and densities, and calculated acoustic impedances of each layer vary in accordance with the individual Zechstein lithologies (Maver et al. 1992). Only carbonate layers show substantial variations in acoustic impedance which may be attributed to porosity variations (Frykman et al. 1992; Fig. 2). Variations in carbonate porosity are therefore expected to be an important contributor to variations in reflectivity and thus to variations in the seismic amplitudepattern.

\section{Seismic modelling}

1D seismic modelling was carried out to determine the extent, to which well derived acoustic impedance logs match the seismic sections and thus to determine the vertical seismic detection limit.

Each computed acoustic impedance log was blocked into intervals of constant acoustic impedance. By changing the complexity of the blocking a suite of models ranging from simple to complex was derived. The blocking of the acoustic impedance log is carried out to define the exact lithologic boundaries and intervals of interest that can be detected by the corresponding seismic section. As the acoustic impedance log has a blocky character which is in accordance with the individual Zechstein lithologies, a valid blocking of the $\log$ into uniform intervals is justifiable. The most simple model resulting in a synthetic seismogram with a reflection pattern corresponding to the synthetic seismogram derived from the original acoustic impedance $\log$ is chosen. This acoustic impedance model is assumed to represent the subsurface detection limit of the seismic section. To reach consistent results the blocking of the acoustic impedance log into a range of models is based on a systematic band pass filtering of the $\log$ at different frequencies in the time domain (Maver 1995b). From a subsequent visual correlation of the calculated synthetic seismogram and the seismic section the chosen blocked acoustic impedance model can be transferred to the seismic section.

The 1D seismic modelling results were used to derive 2D acoustic impedance models and corresponding synthetic seismograms. The velocity and density assigned to each lithology in the 2D models were average values calculated from 5 wells in Southern Jutland (Maver 1995; Fig. 2).

A minimum phase Ricker wavelet (MR) with $1 \frac{1}{2}$ cycles of the dominating frequency is used in the seismic modelling. The time duration of the wavelet present in the seismic data is expected to exceed that of the minimum phase Ricker wavelet. The centre frequency of the Ricker wavelet varies for each derived synthetic seismogram due to different target depths, year of seismic acquisition of the seismic data used for the comparison, and specific subsurface. This centre frequency is indicated on each panel (Figs 3-7).

\section{Data}

The seismic sections were acquired between 1978 and 1987, they are 2D migrated, and they are displayed with white troughs representing increasing acoustic impedance (Fig. 1). As the seismic sections were processed as minimum phase data, resolved reflectors are in general interpreted at zero crossing.

The calibrated long spacing borehole compensated sonic log and the formation density compensated density log were used to compute the acoustic impedance logs. However no sonic and density logs were originally 


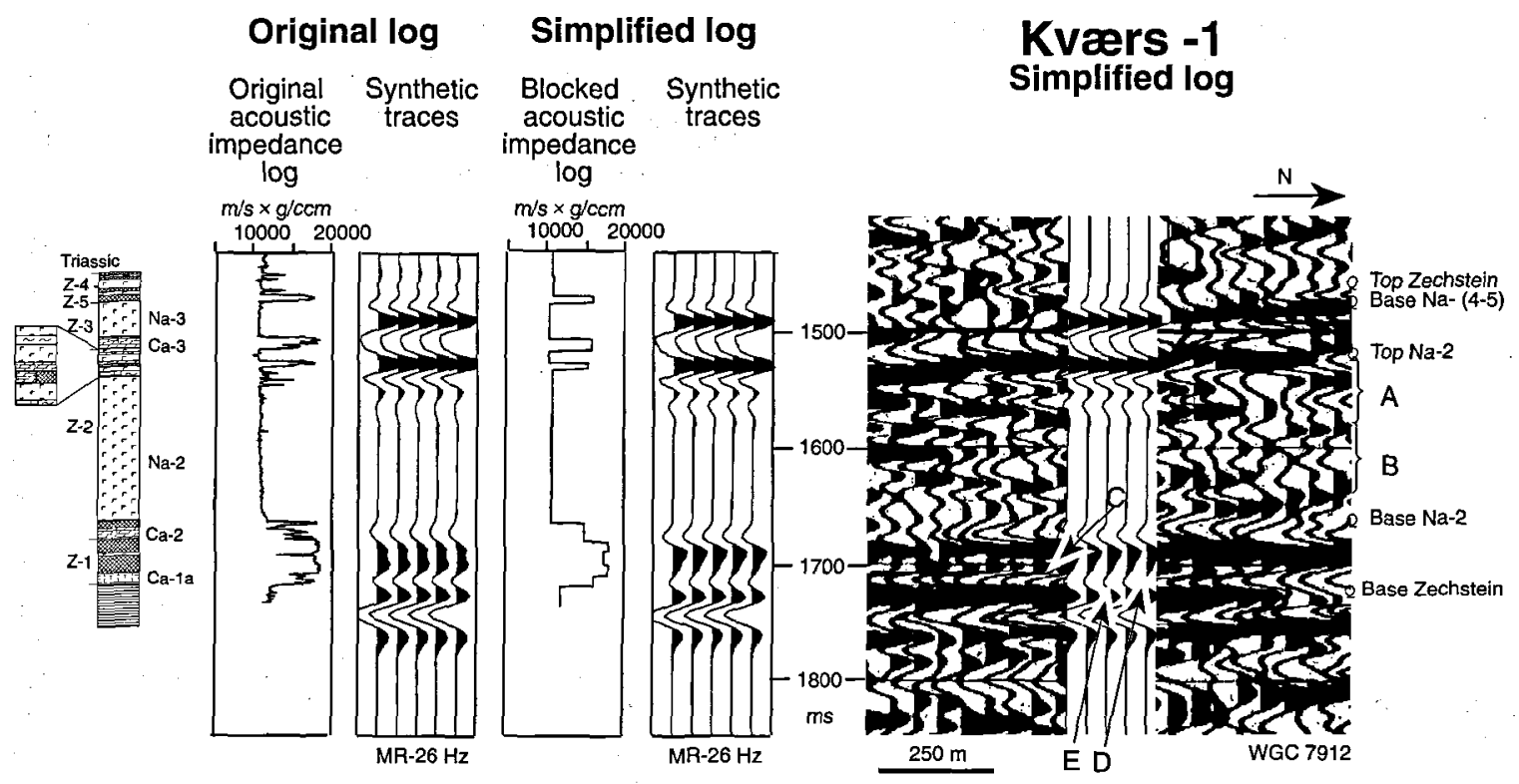

\section{Lithology:}

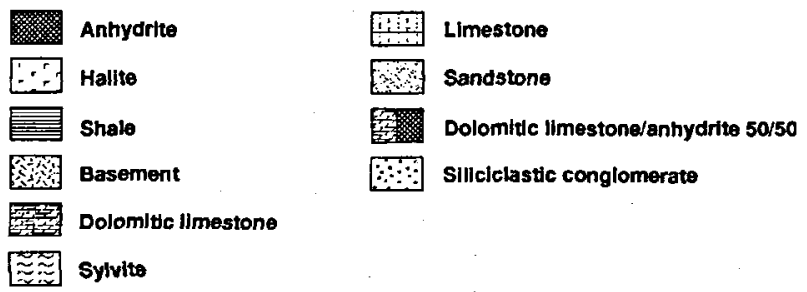

Fig. 3. The Kværs-1 well (Zechstein deposits: $1941 \mathrm{~m}$ $2594 \mathrm{~m}$ below m.sl.). The repetition of 5 traces calculated from the blocked acoustic impedance log is inserted into the seismic section at the location of the Kværs-1 well. Indices are explained in text.

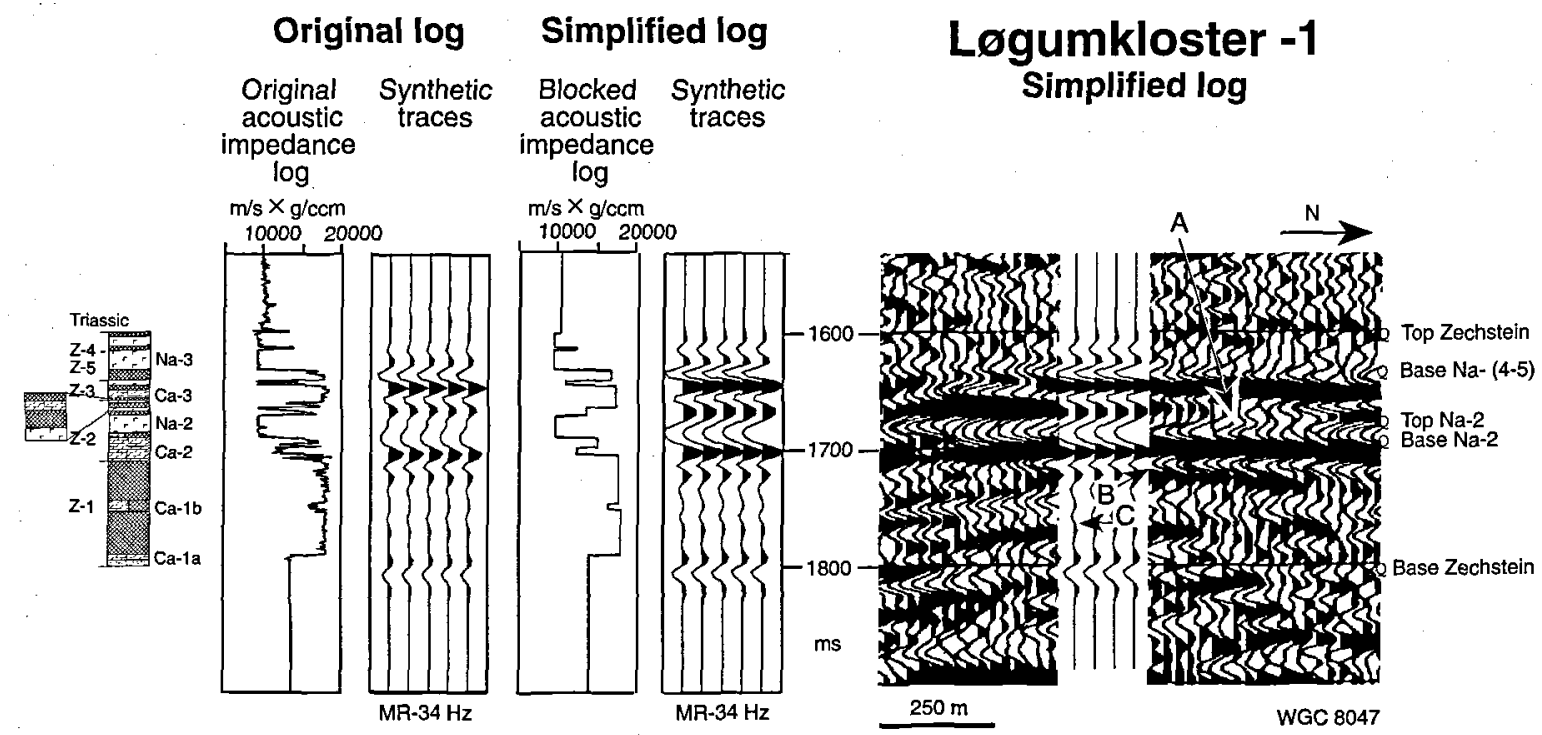

Fig. 4. The Løgumkloster-1 well (Zechstein deposits: $2159 \mathrm{~m}-2690 \mathrm{~m}$ below m.s1.). The repetition of 5 traces calculated from the blocked acoustic impedance log is inserted into the seismic section at the location of the Løgumkloster-1 well. For legend see Fig. 3 and indices explained in text (Lithological log adapted from Stemmerik \& Frykman 1989). 


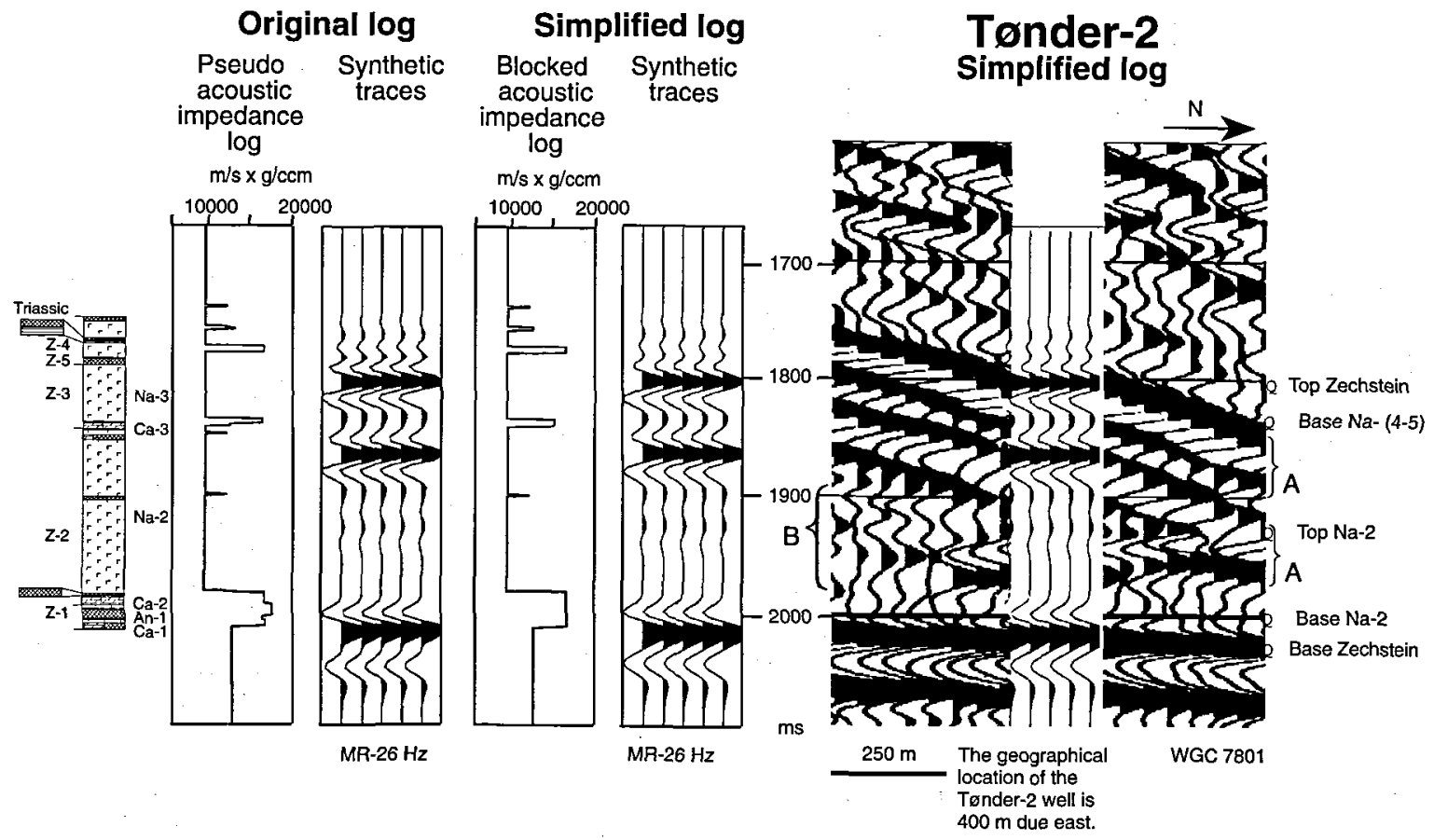

Fig. 5. The Tønder-2 well (Zechstein deposits: $2419 \mathrm{~m}-3070 \mathrm{~m}$ below m.sl.). The repetition of 5 traces calculated from the blocked acoustic impedance log is inserted into the seismic section at the location of the Tønder- 2 well. For legend see Fig. 3 and indices are explained in text (Lithological log adapted from Stemmerik \& Frykman 1989).

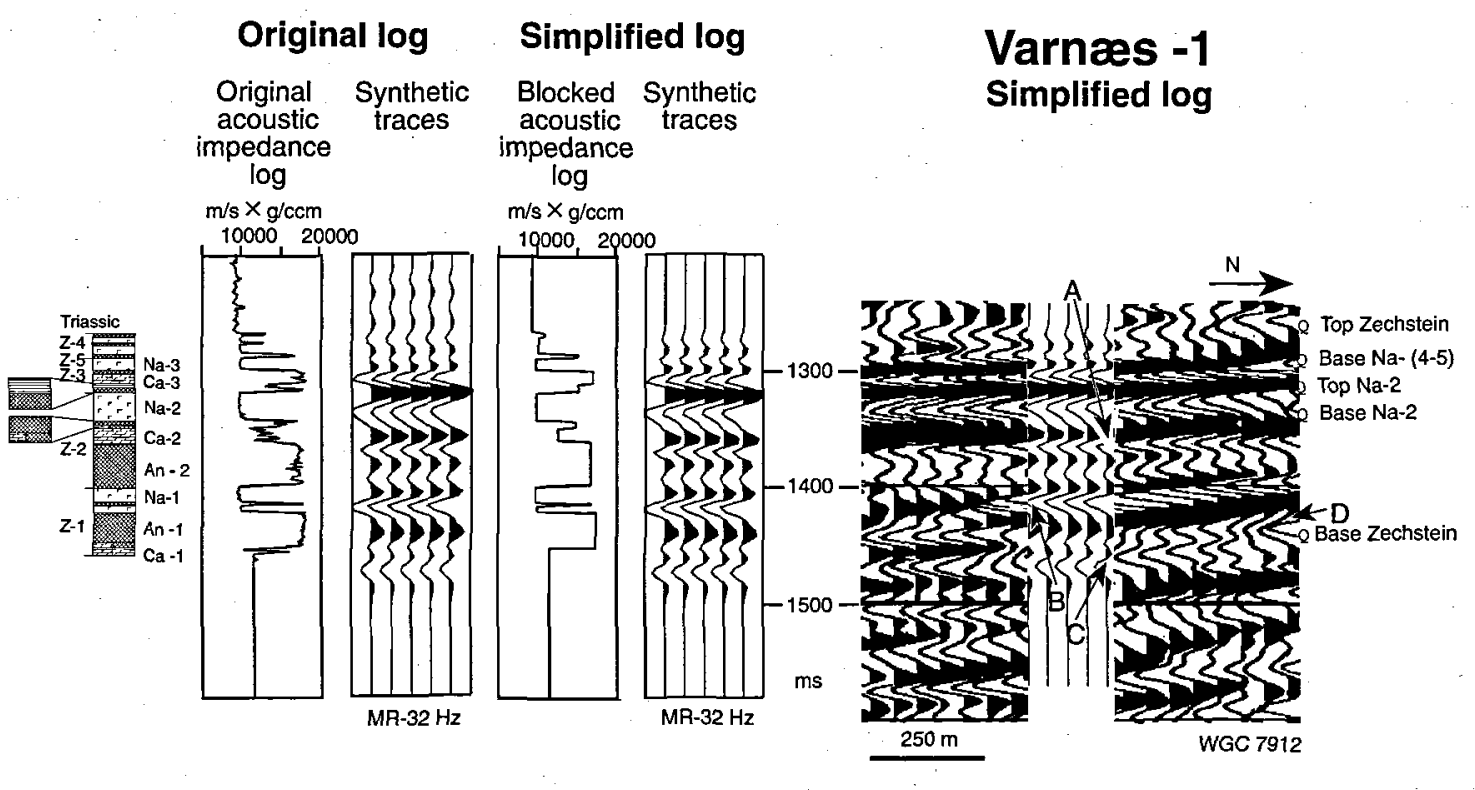

Fig. 6. The Varnæs-1 well (Zechstein deposits: $1661 \mathrm{~m}-2156 \mathrm{~m}$ below m.sl.). The repetition of 5 traces calculated from the blocked acoustic impedance log is inserted into the seismic section at the location of the Varnæs- 1 well. For legend see Fig. 3 and indices are explained in text (Lithological log adapted from Stemmerik \& Frykman 1989). 


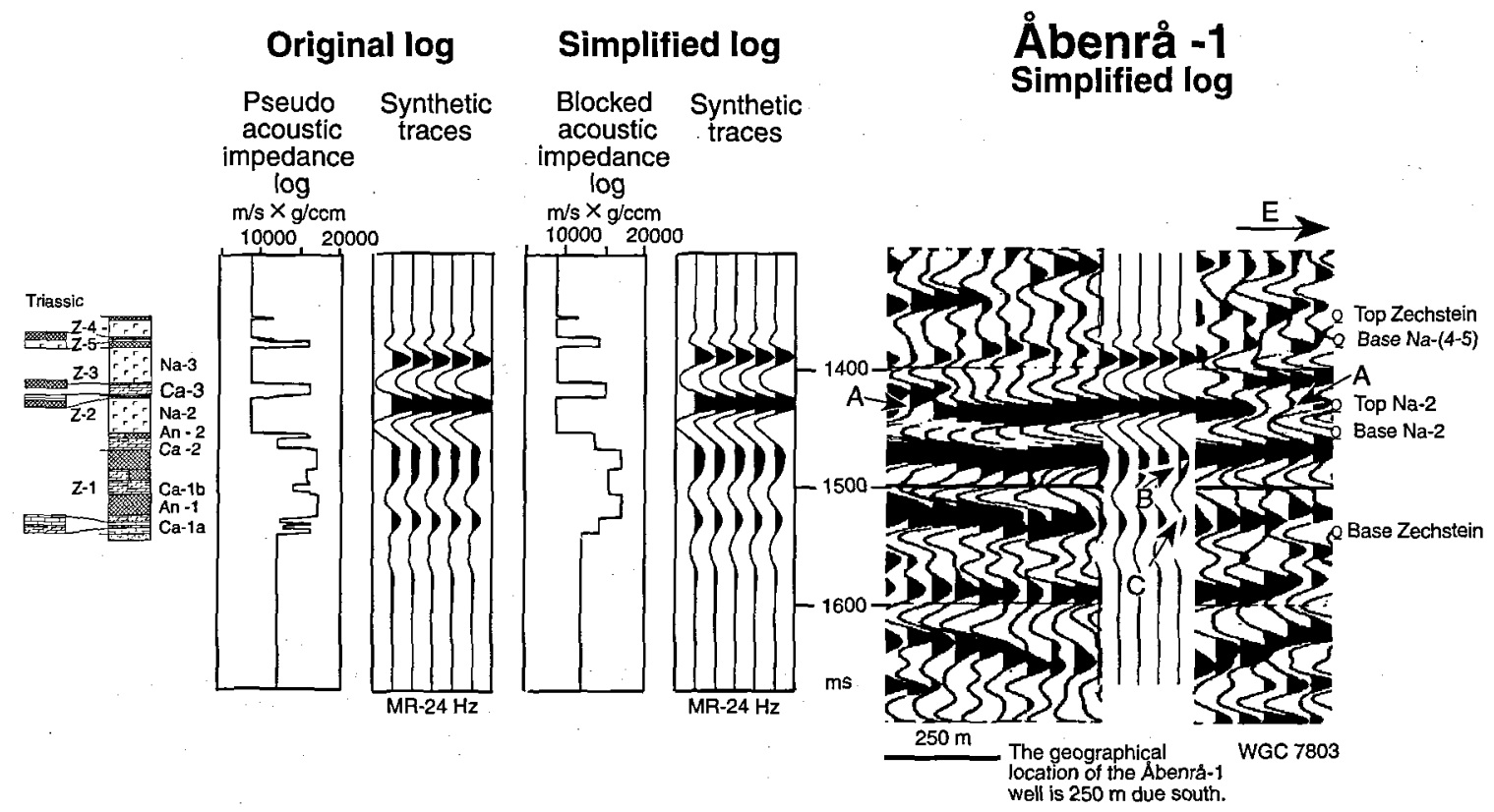

Fig. 7. The Åbenrå-1 well (Zechstein deposits: $1798 \mathrm{~m} \mathrm{-} 2280 \mathrm{~m}$ below m.sl.). The repetition of 5 traces calculated from the blocked acoustic impedance log is inserted into the seismic section at the location of the Åbenrå-1 well. For legend see Fig. 3 and indices explained in text (Lithological log adapted from Stemmerik \& Frykman 1989).

recorded in the 5 old wells drilled in the 1950's (Fig. 1). To utilize the well derived lithological data from these 5 old wells in the seismic modelling study, average velocity and density values were calculated for each Zechstein lithology from 5 other wells in Southern Jutland with sonic and density logs. These values were assigned to the well derived lithological data from the 5 old wells resulting in pseudo velocity and density logs (Maver 1995a). Because the calculated synthetic seismograms for the old wells correlate with the corresponding seismic sections, the pseudo acoustic impedance logs are seen to be valid.

\section{Results}

The acoustic impedance logs from the Kværs-1, Løgumkloster-1, and Varnæs-1 wells and the pseudo acoustic impedance logs from the Tønder-2, and Åbenrå-1 wells have been blocked, and synthetic seismograms have been computed (Figs 3-7). The chosen optimal synthetic seismograms are inserted into the seismic sections.

To reach an optimal correlation the synthetic seismograms are not always inserted into the seismic sections at the exact well locations but at the locations of optimal correlation. The shift of the locations for optimal correlation is indicated on each panel. This is justifiable because: (a) The surface location of the seismic section does not coincide with the exact geographical location of the Tønder-2 and Åbenrå-1 wells (Figs 5 and 7). (b) The seismic reflections do not originate from directly beneath the CMP location due to minor subsurface cross-line dips. (c) A substantial difference in horizontal resolution is present between the seismic sections and the well log recordings. The seismic resolution represented as the first Fresnel zone is approximately $50 \mathrm{~m}$ in the in-line direction and $250 \mathrm{~m}$ in the crossline direction (Maver 1995b). This is in contrast to the well $\log$ resolution that is generally less than one metre (Rider 1986).

The correlation between the synthetic seismograms and the seismic sections is generally good but still not optimal, which can be attributed to the following additional aspects:

(1) The synthetic seismograms are generated by a simple seismic modelling method with a theoretical wavelet of minimum phase. A wavelet estimated from the seismic data is generally of mixed phase and has a longer time duration than the theoretical wavelet (See Maver 1995b). The differences between the seismic wavelet and the theoretical wavelet become apparent especially at the layer interfaces for the homogenous halite layers in the basinal area (Figs 3-A and 5-A).

(2) Especially within the thick homogeneous $\mathrm{Na}-2$ halite layer no reflections are modelled. Part of the internal seismic reflection pattern associated with this layer is therefore assumed to represent noise and multiples (Figs 3-B and 5-B).

(3) No logs exist from the Tønder-2 and Åbenrå-1 wells. The synthetic seismograms are calculated from 
Table 1. Division of seismic reflection patterns associated with the Ca-2 carbonate layer in accordance with porosity and interval thickness.

\begin{tabular}{|c|c|c|c|c|}
\hline & $\begin{array}{l}\text { Reflection character } \\
\text { below black peak } \\
\text { reflection: Fig. 8-BPR }\end{array}$ & $\begin{array}{l}\text { Variations in porosity } \\
\text { and thickness. }\end{array}$ & $\begin{array}{l}\text { Associated reflection } \\
\text { patterns at wells. }\end{array}$ & Mapped distribution. \\
\hline I & $\begin{array}{l}\text { No black peak and white } \\
\text { trough. }\end{array}$ & $\begin{array}{c}0-4 \mathrm{~m}, 20 \% \\
14 \mathrm{~m}, 0-12 \% \\
14 \mathrm{~m}, 20 \% / \\
0-2 \mathrm{~m} \mathrm{An}-2\end{array}$ & & $\begin{array}{c}\text { No porous } \\
\text { carbonate resolved. }\end{array}$ \\
\hline II & $\begin{array}{l}\text { White trough and minor } \\
\text { black peak }\end{array}$ & $\begin{array}{c}8-16 \mathrm{~m}, 20 \% \\
14 \mathrm{~m}, 15-30 \% \\
14 \mathrm{~m}, 20 \% / \\
9-14 \mathrm{~m} \mathrm{An}-2\end{array}$ & $\begin{array}{l}\text { Løgumkloster-1, } \\
\text { Fig. 4-B. } \\
\text { Varnæs-1, } \\
\text { Fig. 6-A }\end{array}$ & $\begin{array}{l}8-14 \mathrm{~m}, 20 \% \\
14 \mathrm{~m}, 15-30 \%\end{array}$ \\
\hline III & $\begin{array}{l}\text { White trough and } \\
\text { prominent black peak. }\end{array}$ & $\begin{array}{c}16-33 \mathrm{~m}, 20 \% \\
14 \mathrm{~m}, 20 \% / \\
14-25 \mathrm{~m} \mathrm{An}-2\end{array}$ & & $14-33 \mathrm{~m}, 20 \%$ \\
\hline IV & $\begin{array}{l}\text { Large wavelength white } \\
\text { trough and black peak. }\end{array}$ & $\begin{array}{c}33-40 \mathrm{~m} 20 \% \\
14 \mathrm{~m}, 20 \% ! \\
25-30 \mathrm{~m} \mathrm{An}-2\end{array}$ & & $\begin{array}{c}14 \mathrm{~m}, 20 \% \\
33-40 \mathrm{~m}, 20 \%\end{array}$ \\
\hline $\mathrm{V}$ & $\begin{array}{l}\text { Large wavelength black } \\
\text { peak or double black } \\
\text { peak }\end{array}$ & $\begin{array}{l}14 \mathrm{~m}, 20 \% / \\
2-9 \mathrm{~m} \mathrm{An}-2\end{array}$ & $\begin{array}{l}\text { Kværs-1, Fig. 3-C } \\
\text { Åbenrå-1, Fig. 7-B. }\end{array}$ & $\begin{array}{l}8-14 \mathrm{~m}, 20 \% \\
14 \mathrm{~m}, 15-30 \%\end{array}$ \\
\hline
\end{tabular}

derived pseudo acoustic impedance logs (Figs 5 and 7).

(4) As the T.D. of the wells lies directly beneath the Zechstein Group, this makes the modelled reflection pattern associated with the base Zechstein boundary incomplete.

From the seismic modelling results it is found that the top and the base Zechstein boundary generally can be correlated between the synthetic seismograms and the seismic sections, even though amplitude differences are present (Figs 3-7). Thus, an interpretation of the seismic reflections associated with the two boundaries is possible. The base of the $\mathrm{Na}-(4-5)$ halite layer and both the top and base of the $\mathrm{Na}-2$ halite layer are resolved and can be correlated between the synthetic seismograms and the seismic sections, and the associated seismic reflections are furthermore persistently imaged in the seismic sections (Figs 3-7).

Within this seismic reflection framework variations in carbonate porosity generate diagnostic reflection patterns. Variations in carbonate porosity are described in accordance with a four fold subdivision illustrated in Fig. 2. The subdivision is based on the variations of carbonate porosity found in the wells and the variations found in the seismic data.

\section{$\mathrm{Ca}-3, \mathrm{Ca}-1 \mathrm{~b}$, and $\mathrm{Ca}-1 \mathrm{a}$ carbonate layers}

Low porosity $\mathrm{Ca}-3$ carbonate has been found in all the wells (Figs 3-7). The only exception is a thin interval with high porosity (up to approximately $15 \%$ ) at the Løgumkloster-1 well (Fig. 4). Due to the generally thin carbonate layer and the associated low porosity where the acoustic impedance corresponds to that of the surrounding layers, it is not detected by the synthetic seismograms as illustrated by the simplified logs. However, the carbonate layer correlates with a seismic reflection pattern with significant amplitude variations and phase changes at the Løgumkloster-1 and Åbenrå1 wells (Figs $4-A$ and $7-A$ ). This may reflect either patches of porous carbonate or seismic interference pattern between base of $\mathrm{Na}-3$ halite and top of the Na2 halite, due to a general decrease in An-3 halite layer thickness. As the size of the areas of amplitude variations often equals the size of the first Fresnel zone, the resolved appearance of the subsurface is somewhat distorted. Furthermore, the seismic database is irregular, which makes it impossible to correlate the patches of potentially porous $\mathrm{Ca}-3$ carbonate between seismic sections.

The Ca-1b carbonate layer has a medium porosity and is partly detected by the seismic data at the Åbenrå1 well, but the corresponding reflection pattern is not interpretable with respect to this specific interval (Fig. 7). The carbonate-anhydrite mixture layer at the L $\emptyset$ gumkloster-1 well is detected, but the synthetic reflection pattern is difficult to correlate with the seismic section (Fig. 4). At the wells Kværs-1 and Varnæs-1 $\mathrm{Na}-1$ halite is found instead of $\mathrm{Ca}-1 \mathrm{~b}$ carbonate, and the interval is only partly detected at the Kværs- 1 well (Fig. 3-D). The detected Na-1 halite layer results in an 


\section{Ca-2 porous carbonate interval}

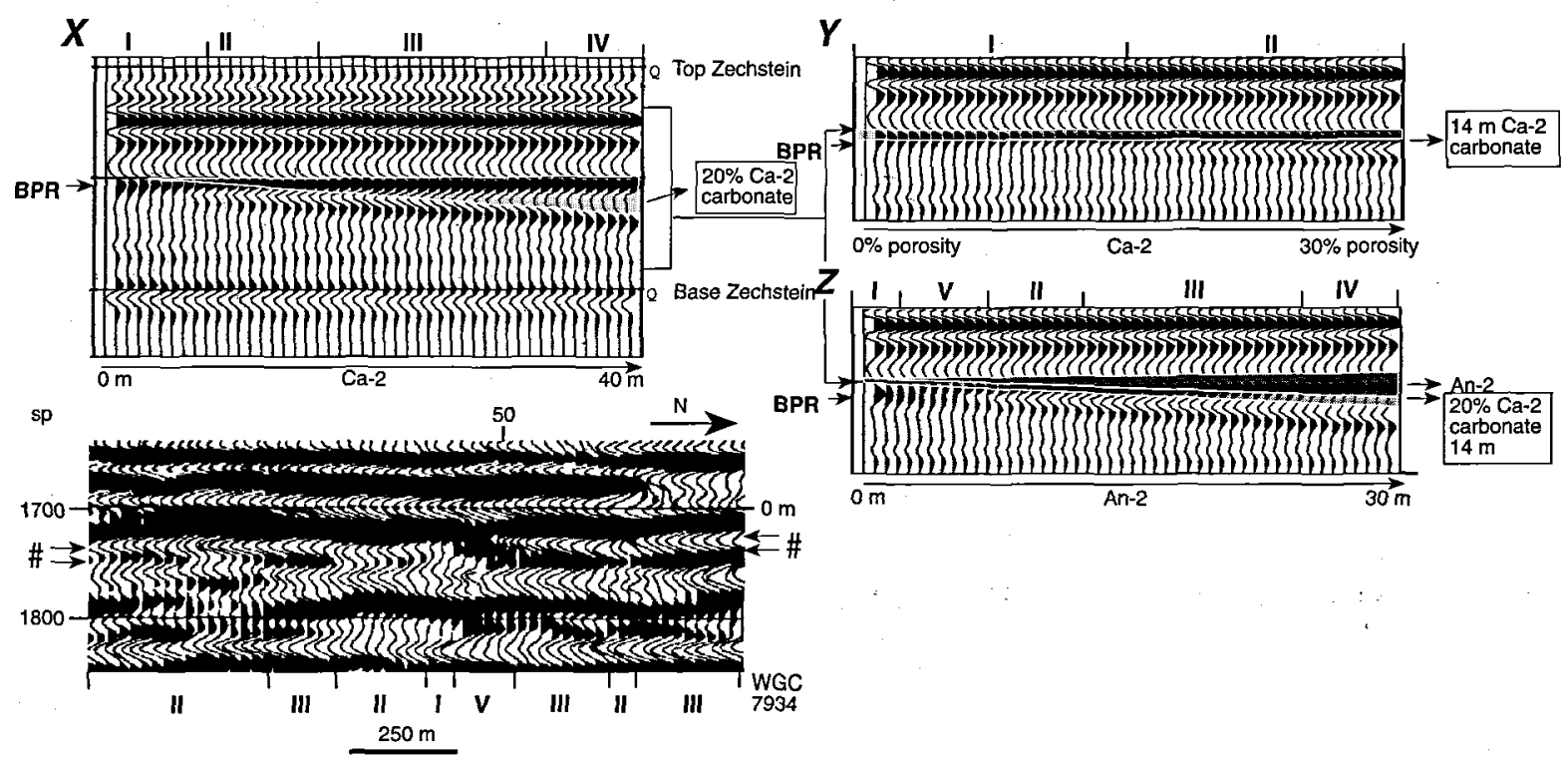

Fig. 8. The influence of the porous $\mathrm{Ca}-2$ carbonate interval on the reflection pattern according to thickness, porosity and the thickness of the An-2 anhydrite layer. The corresponding diagnostic reflection pattern is subdivided into 5 categories (I-V) and illustrated by seismic section WGC 7934 .

easily interpretable reflection pattern at the Varnæs-1 well (Fig. 6-B). The reflection pattern associated with either the carbonate-anhydrite mixture layer or the $\mathrm{Na}$ 1 halite layer can in general not be distinguished from that of a porous $\mathrm{Ca}-1 \mathrm{~b}$ carbonate interval because the acoustic impedance is lower than that of the surrounding layers and results in similar seismic reflection patterns. The Ca-1b carbonate layer was not encountered in the Tønder-2 well (Fig. 5).

In general the seismic reflection pattern indicating the presence of porous $\mathrm{Ca}-1 \mathrm{~b}$ carbonate is ambiguous. The reflections associated with an overlying thick porous $\mathrm{Ca}-2$ carbonate interval furthermore influence the reflection pattern of the Ca- $1 \mathrm{~b}$ carbonate interval. This makes it difficult to determine exactly the extent, to which the porous $\mathrm{Ca}-\mathrm{Hb}$ carbonate interval is detected by the seismic sections.

The medium to high porosity of the Ca-1a carbonate layer is detected at the Åbenrå-1 well as a black peak shifted upwards (Fig. 7-C). This black peak is generally associated with base Zechstein. The low to high porosity carbonate interval at the Varnæs-1 well is not detected by the synthetic seismogram (Fig. 6). The decrease in the amplitude of the black peak reflection generally associated with the base Zechstein boundary is possibly due to the influence of the over-lying reflections of the Na-1 halite layer (Fig. 6-C). And as the An-1 anhydrite layer thins, the influence of the overlying $\mathrm{Na}-1$ halite layer increases resulting in a phase reversal of the black peak reflection (Fig. 6-D).
Due to a low porosity the carbonate layer has an acoustic impedance similar to the overlaying anhydrite layer, and is thus not detected at the Løgumkloster-1 and Tønder-2 wells (Figs 4 and 5). The medium porous carbonate interval found at the Kværs-1 well is detected, however the corresponding reflection pattern is difficult to interpret (Fig. 3-E).

The porous part of the $\mathrm{Ca}-1 \mathrm{a}$ carbonate layer is not clearly detected by the seismic sections. The base Zechstein boundary is furthermore irregular due to variable basement subsidence and faulting. Noise is present in the seismic sections, and the interference of reflections from the low acoustic impedance layers (halite, porous carbonate or carbonate-anhydrite mixture) above the $\mathrm{Ca}-1 \mathrm{a}$ carbonate layer influence the base Zechstein reflection pattern. Precambrian crystalline basement, Lower Palaeozoic rocks (Caledonian) and Lower Permian Rotliegende sediments are furthermore found below the Ca-la carbonate layer (Stemmerik \& Frykman 1989) resulting in a variable reflectivity at the base Zechstein boundary. Numerous settings may generate a base Zechstein reflection pattern that is indicative of porous Ca-1a carbonate. Distinguishing between a porous $\mathrm{Ca}-1 \mathrm{a}$ carbonate interval and other factors generating a diagnostic base Zechstein black peak reflection is thus not possible.

Due to the ambiguous detection of the porous $\mathrm{Ca}-3$, $\mathrm{Ca}-1 \mathrm{~b}$, and $\mathrm{Ca}-1 \mathrm{a}$ carbonate the intervals have not been mapped, but the possible lateral distribution is described later. 


\section{Ca-2 porous carbonate interval}

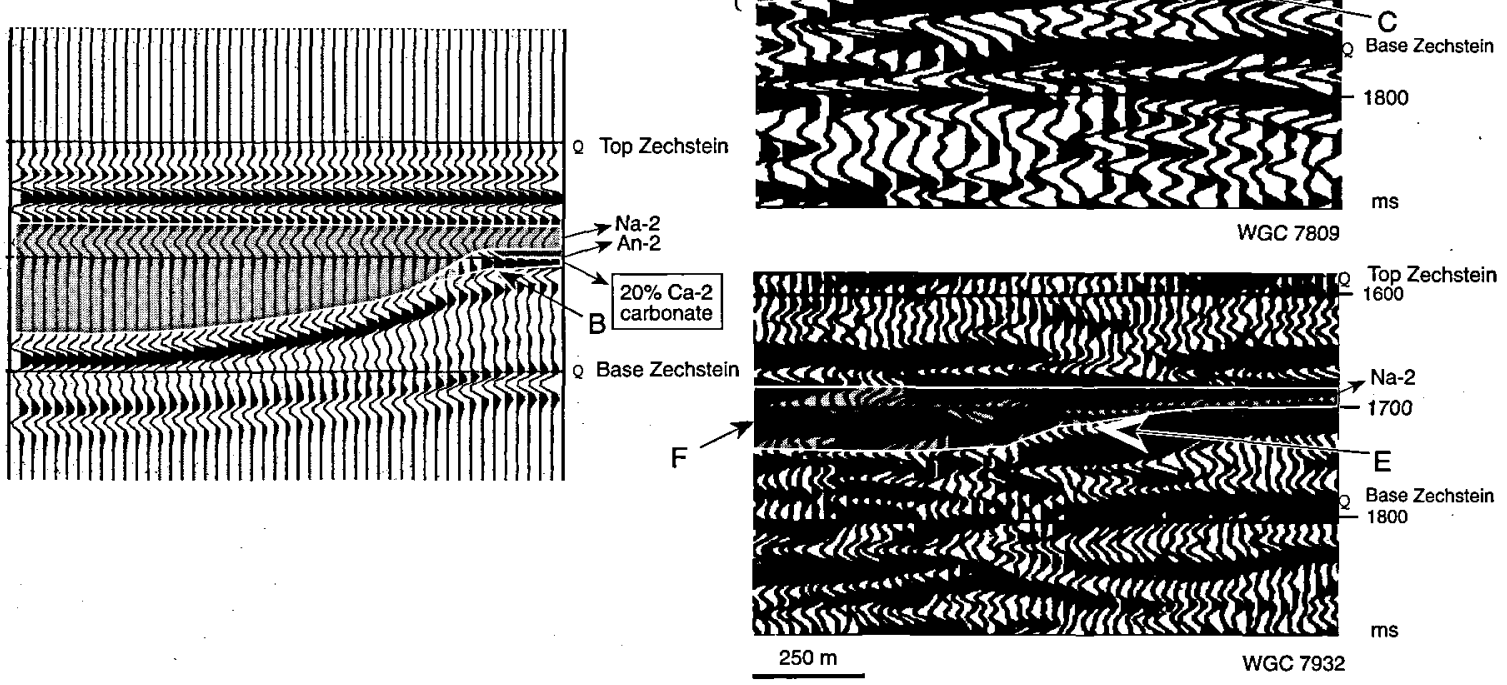

Fig. 9. Synthetic seismogram from an empirically derived acoustic impedance model with the porous $\mathrm{Ca}-2$ carbonate layer and $\mathrm{Na}-2$ halite layer at the platform edge. Indices are explained in text.

\section{Ca- 2 carbonate layer}

The Ca- 2 carbonate layer has a medium to high porosity at the Kværs- 1 and Åbenrå-1 wells, but cannot be separately detected from the surrounding carbonateanhydrite mixture layer (Figs 3 and 7). The $\mathrm{Ca}-2$ carbonate layer correlates with a diagnostically large wavelength/double amplitude black peak reflection at the Kværs- 1 and Åbenrå-1 wells which is indicative of porous carbonate (Figs 3-C and 7-B). The high porosity part of the Ca-2 carbonate layer at the Løgumkloster1 and Varnæs-1 wells is clearly detected and represented as a composite reflection pattern consisting of a white trough and black peak (Figs 4-B and 6-A). At the Tønder- 2 well the carbonate layer has a low porosity and is not detected (Fig. 5).

To evaluate the porous $\mathrm{Ca}-2$ carbonate depositional setting detected by the seismic sections, a forward modelling study was carried out with 3 different cases based on the derived 1D model at the Løgumkloster-1 well with a 14 m thick $20 \%$ porous $\mathrm{Ca}-2$ carbonate interval (Fig. 4). The thickness of this porous carbonate interval with $20 \%$ porosity is varied from 0 to $40 \mathrm{~m}$ in model X, the porosity of the $14 \mathrm{~m}$ thick $\mathrm{Ca}-2$ carbonate interval is varied from 0 to $30 \%$ in model Y, and finally the thickness of the An-2 anhydrite layer above the 14 $\mathrm{m}$ thick $20 \%$ porous carbonate interval is varied from $0 \mathrm{~m}$ to $30 \mathrm{~m}$ in model $\mathrm{Z}$ (Fig. 8). The seismic tuning effect caused by the presence of the An-2 anhydrite layer overlying the $\mathrm{Ca}-2$ carbonate layer has been noted by Mathisen \& Budny (1990). From the seismic modelling results, 5 reflection patterns (Table 1) diagnostic of the Ca-2 carbonate layer are defined below the prominent black peak reflection (Fig. 8-BPR). These 5 diagnostic reflection patterns are indicated on the representative seismic section WGC 7934 in association with the Ca-2 carbonate layer (Fig. 8-\#). The modelling results illustrate the uncertainties associated with an interpretation of a porous carbonate interval in the seismic sections.

On the Zechstein platform towards the edge the reflection pattern associated with the porous $\mathrm{Ca}-2$ carbonate interval (Fig. 9-AI) indicates the presence of a porous build-up with a substantial thickness towards the basin (Fig. 9-AII). This is similar to the seismic reflection pattern seen at the Løgumkloster-1 and Varnæs-1 wells (Figs 4-B and 6-A). From a 2D acoustic impedance model it can be shown, that an increased Na-2 halite layer thickness can result in a seismic reflection pattern, where a continuous black peak reflection is generated in the basinal area being the top $\mathrm{Na}-2$ postcursor. In the platform area the top $\mathrm{Na}-2$ postcursor overly the $\mathrm{Ca}-2$ carbonate and thus 
appears to cross the base $\mathrm{Na}-2$ halite surface in between (Fig. 9-B). This reflection pattern is seen in the seismic sections in association with the porous $\mathrm{Ca}-2$ carbonate interval (Fig. 9-C). The diagnostic reflection pattern is attributed to the presence of the full extent of the wavelet and Zechstein interbed multiples being resolved in the seismic sections within the thick homogenous Na-2 halite layer. In the synthetic seismogram the black peak reflection is not as prominent due to the simple modelling approach (Fig. 9-B). The presence of a thick $\mathrm{Na}-2$ halite layer instead of porous carbonate is supported by the overlaying reflection pattern, which is shallower in TWT time than elsewhere (Fig. 9-D). The uplift can indicate underlying halite migration, which requires a thick $\mathrm{Na}-2$ halite layer to be present. On a few seismic sections, however, it is more obvious that an increased $\mathrm{Na}-2$ halite thickness is present, as the top Na-2 black peak reflection postcursor is not continuous where it crosses the base Na-2 halite surface (Fig. 9-E).

The seismic sections are interpreted with reference to this uncertain definition of the variation in $\mathrm{Ca}-2$ carbonate porosity (Fig. 10). Minor details are not mapped, and the various reflection patterns are connected between the seismic sections, even though the seismic database has variable density (Fig. 1).

\section{Discussion}

From the seismic data and the 10 wells Southern Jutland has been subdivided into two prominent areas; the basinal and platform area. The platform edge is defined where the $\mathrm{Na}-2$ halite layer exceeds a thickness of approximately $100 \mathrm{~m}$. From this interpretation the platform edge and the Pre Zechstein fault pattern do not entirely coincide (Figs 1 and 10). Differential deposition of anhydrite and carbonate during the late Z-1 and early Z-2 cycles therefore seems to have been the dominating factor in the build-up of the platform, and syn-sedimentary faulting has only played a minor role as predicted by Stemmerik \& Frykman (1989).

The TWT time structure map in Figure 10 generally illustrates the actual subsurface in depth, as a simple velocity distribution exists for the Post Zechstein deposits with the exception of the delineated Post Zechstein fault zone. The well data indicates that the 4 carbonate layers have a low porosity in the basinal area, and no porous carbonate intervals are detected by the seismic sections (Fig. 10). On the platform all carbonate layers are found to have a variable porosity in the well data, and the porous carbonate intervals are detected by the seismic sections.

The predicted distribution of porous carbonate intervals is not representative for the present variations, as only the porous part of the carbonate layers detected by the seismic sections is interpreted. Furthermore, the porosity and thickness of each seismically detected carbonate interval are partly interchangeable without significantly influencing the seismic reflection pattern, thereby making the porosity prediction uncertain. But even with this uncertain detection of the porous carbonate intervals, the derived lateral porosity distribution agrees with the predicted carbonate facies distribution and depositional setting derived from the well data in Southern Jutland.

A seismic reflection pattern indicating the presence of porous Ca-1a carbonate is found locally on the platform with increasing intensity towards the platform edge (Fig. 1). The lateral extent of the detected inter$\mathrm{val}$ is limited and seldom exceeds $500 \mathrm{~m}$, and the thickness is not expected to exceed $10 \mathrm{~m}$. The possible lateral porosity distribution agrees in general with the prediction from the well data, where Ca-1a carbonate is widely distributed in Southern Jutland, and a possible patch reef depositional setting appears to have been restricted mostly to the eastern part of the platform (Stemmerik et al. 1987).

On the platform towards the edge, the seismic reflection pattern indicating the presence of $\mathrm{Ca}-1 \mathrm{~b}$ porous carbonate is not especially prominent (Fig. 1). Towards the north on the interior of the platform the $\mathrm{Ca}-1 \mathrm{~b}$ carbonate layer may be porous over detected lengths as large as one kilometre. But the seismic reflection pattern could equally be indicative of a carbonate-anhydrite mixture on the western half of the Zechstein platform. And on the eastern part of the platform it is most likely, that the prominent reflection pattern is associated with Na-1 halite as seen at the Varnæs-1 well (Fig. 6-B). The status of the unit should be considered with care in a stratigraphic study (Stemmerik et al. 1987).

The porous $\mathrm{Ca}-2$ carbonate interval is generally thick in large elongated areas on the platform partly parallel to the edge and especially in the vicinity of and to the north of the Løgumkloster-1 well and at the Kværs1 well (Fig. 10). 4 structural closures are associated with the porous $\mathrm{Ca}-2$ carbonate interval, but only at the Løgumkloster-1 well and to the west of the Kværs1 well is substantial porosity present (Fig. 10). The structures mapped within the Post Zechstein fault zone and at the Tønder wells are caused by overlying halite structures resulting in velocity pull-ups of the underlying seismic reflection pattern.

The mapped distribution of porous $\mathrm{Ca}-2$ carbonate presumably corresponds to the high energy porous oolite shoals that are predicted to be present at the platform edge (Stemmerik \& Frykman 1989). The leeward side of the oolitic shoals was periodically supplied with oolitic sediment, which spilled over the shoals during storms. Landward from the shoals oolitic material became less important, and wider protected lagoons prevailed. Moderately agitated open lagoons apparently developed in localized areas probably with more frequent connection to the open marine environment outside the oolite barrier. A similar distribution of porous oolite deposits hasbeen described from the Netherlands (Maureau \& van Wijhe 1979). 


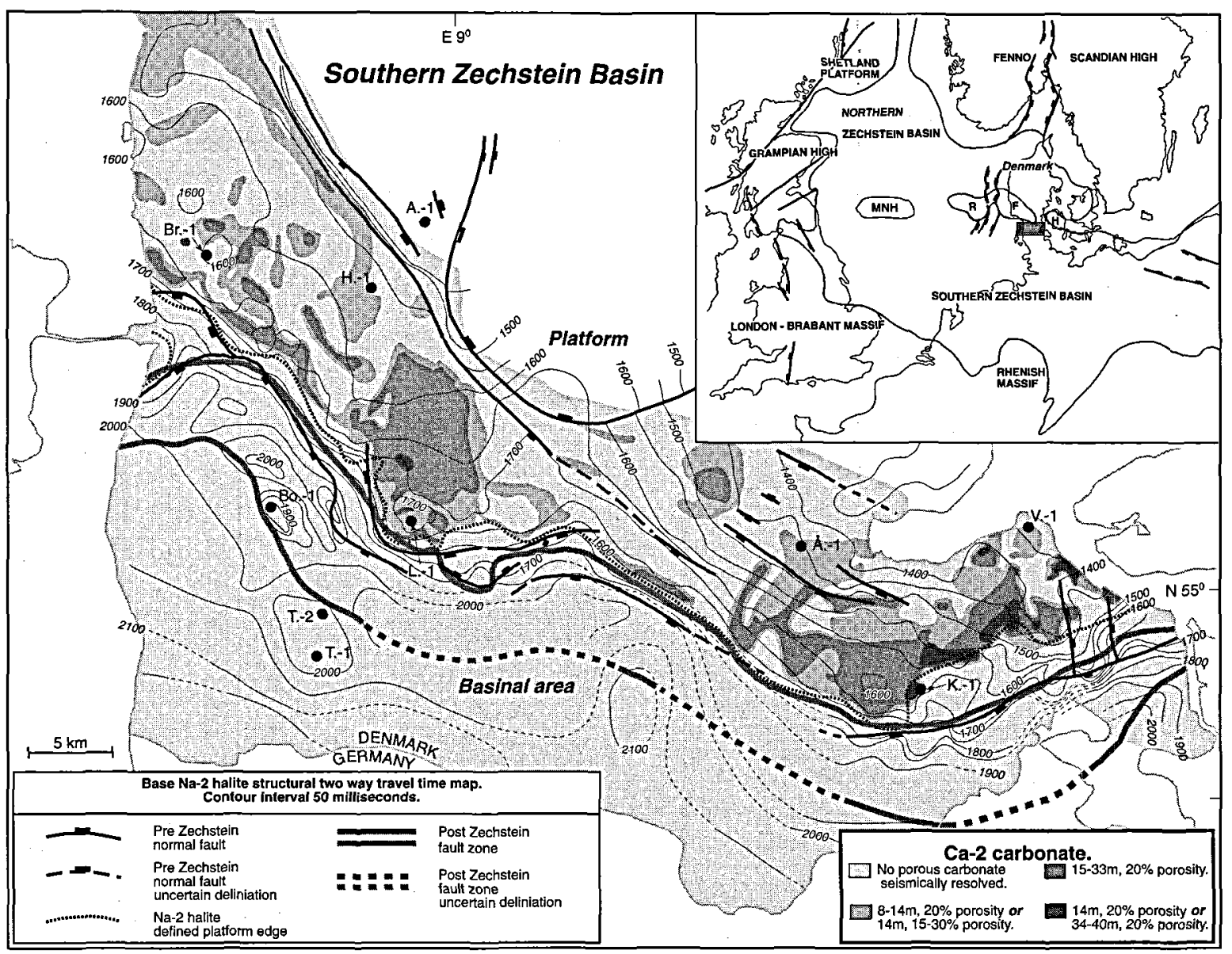

Fig. 10. The seismically mapped distribution of the porous Ca- 2 carbonate interval. Mapped porosity distribution based on Table 1 and Fig. 8. A.-1; Arnum-1, Bo.-1; Borg-1, Br.-1; Brøns-1, H.-1; Hønning-1, K.-1; Kværs-1, L.-1; Løgumkloster-1, T.-1; Tønder-1, T.-2; Tønder-2, V.-1; Varnæs-1 and Å.-1; Åbenrå-1.

An indication of porous $\mathrm{Ca}-3$ carbonate is found as isolated patches with a length of between $200 \mathrm{~m}$ and $1200 \mathrm{~m}$ on the platform located mostly towards the edge in the vicinity of the Løgumkloster-1 well and on the western part of the platform. At the time of deposition of $\mathrm{Ca}-3$ carbonate the Southern Zechstein Basin was filled and no relief existed in the area (Clark \& Tallbacka 1980). The thin Ca-3 carbonate layer represents localised lagoonal deposits restricted to exposed areas with some circulation (Stemmerik \& Frykman 1989).

\section{Conclusion}

The seismic modelling supported interpretation has resulted in a prediction of the lateral distribution of porous carbonate intervals in Southern Jutland:

(1) No porous carbonate intervals are detected by the available seismic sections in the basinal part of the Southern Zechstein Basin.

(2) The lateral distribution of the porous $\mathrm{Ca}-2$ carbonate interval is uncertain, but it is predicted to have a substantial thickness especially on the Zechstein platform towards the edge. The Ca-3 carbonate layer is potentially porous in small patches, and the $\mathrm{Ca}-1 \mathrm{a}$ and $\mathrm{Ca}-1 \mathrm{~b}$ porous carbonate intervals are thin and scarce and are not consistently detected by the seismic sections on the Zechstein platform.

(3) The model study of the distribution of the porous $\mathrm{Ca}-2$ carbonate interval and the $\mathrm{Na}-2$ halite layer illustrates how the platform edge is located further to the north than immediately apparent from the seismic reflection pattern. Exploration wells that target the porous $\mathrm{Ca}-2$ carbonate interval at the platform edge, have to be located carefully to avoid encountering a thick Na-2 halite layer instead.

(4) The seismic interpretation shows that the struc- 
tural traps associated with the Ca-2 porous carbonate interval are not especially prominent.

(5) As producing carbonate fields in western Poland have average matrix porosities of up to $10.6 \%$ (Depowski \& Peryt 1985), potential hydrocarbon bearing carbonate intervals with a low porosity are likely to be overlooked in Southern Jutland with the present seismic resolution.

\section{Acknowledgements}

I am thankful to Hans Thybo, University of Copenhagen and to Claus Andersen, Geological Survey of Denmark for many suggestions that have improved this paper. The work has been financially supported by the Danish Research Academy. Thanks are also due to Benny Schack and Gitte Nicholaisen for drafting.

\section{Dansk sammendrag}

Zechstein karbonat aflejringer i Det sydlige Jylland, Danmark, er blevet undersøgt i forbindelse med kulbrinteforskning. 10 boringer er blevet gennemført siden 1952 og mere end $2000 \mathrm{~km}$ seismiske data er blevet indsamlet af forskellige selskaber. Ved at anvende de indsamlede boredata, i form af borehulslogs, er seismisk modellering blevet anvendt, som et hjælpemiddel til forudsigelse af den horisontale udbredelse af porøse Zechstein karbonatlag fra den omfattende seismiske database.

1D seismisk modellering er blevet anvendt til at definere det maksimale antal intervaller fra den beregnede akustiske impedanslog, som er representeret i de seismiske data. De 1D seismiske modelleringsresultater er dernæst blevet anvendt til at udlede 2D akustiske impedansmodeller og tilhørende syntetiske seismogrammer. Den seismiske modellering er således blevet anvendt til at illustrere en række reflektionsmønstre, der er karakteristiske for porøse karbonat lag i de seismiske data. Den forudsagte fordeling af porøse karbonatintervaller er dog usikker, fordi tykkelses- og porøsitetsvariationer for det enkelte karbonatlag ikke kan adskilles. Derudover har det vist sig at tynde porøse karbonat intervaller ikke er repræsenteret $\mathrm{i}$ de seismiske data og at det seismiske reflektionsmønster, som indikerer tilstedeværelsen af porøs karbonat, kan vare forbundet med andre litologier.

Porøse Ca-1a, Ca-1b, Ca-2 and Ca-3 karbonatintervaller er repræsenteret $i$ de seismiske data, men kun $i$ Zechstein platformområdet. Det er kun muligt at foretage en egentlig kort lægning af det porøse $\mathrm{Ca}-2$ karbonatinterval, mens det er muligt at give en indikation af fordelingen af de andre porøse karbonatintervaller.

\section{References}

Antonowicz, L. \& Knieszner, L. 1984: Zechstein reefs of the main dolomite in Poland and their seismic recognition. Acta Geologica Polonica 34, 81-93.

Budny, M. 1991: Seismic reservoir interpretation of Permian carbonates and sandstones (NW Germany gas province). First Break 9, 55-64.

Clark, D. N. 1986: The distribution of porosity in Zechstein carbonates. In Brooks, J., Gof, J. C. \& van Hoorn, B. (eds) Habitat of Paleozoic gas in NW. Europe, Geological Society Special Publication 23, 121-149.

Clark, D. N. \& Tallbacka, L. 1980: The Zechstein deposits of southern Denmark. Contribution to Sedimentology 9 , 205-231.

Depowski, S. \& Peryt, T. M. 1985: Carbonate petroleum reservoirs in the Permian dolomites of the Zechstein ForeSudetic area, Western Poland. In Roehl, P. O. \& Choquette, P. W. (eds) Carbonate petroleum reservoirs, 251 264. New York: Springer-Verlag.

Frykman, P., Stentoft, N., Rasmussen, K. L., Christensen, O. W., Andersen, P. V. \& Jacobsen, F. L. 1992: Diagenesis and porous system in Danish Zechstein carbonate reservoirs. In Frias, M. (ed.) Optimization of the production and utilization of hydrocarbons, 160-171. London: Graham \& Trotman.

Jenyon, M. K. \& Cresswell, P. M. 1987: The southern Zechstein salt basin in the British North Sea, as observed in regional seismic traverses. In Brooks, J. \& Glennie, K. (eds) Petroleum Geology of North West Europe, 277-292. London: Graham \& Trotman.

Jenyon, M. K. \& Taylor, J. C. M. 1983: Hydrocarbon indications associated with North Sea Zechstein shelf features. Oil and Gas Journal, Dec 5, 155-160.

Maureau, G. T. F. R. \& van Wijhe, D. H. 1979: The prediction of porosity in the Permian (Zechstein 2) carbonate of eastern Netherlands using seismic data. Geophysics 44, 1502-1517.

Mathisen, M. E. \& Budny, M. 1990: Seismic lithostratigraphy of deep subset Permo-Carboniferous gas reservoirs, Northwest German Basin. Geophysics 55, 1357-1365.

Maver, K. G., 1995a: Comparison of acoustic impedance logs with seismic sections by modelling of reflection patterns. Ph.D. Thesis. University of Copenhagen.

Maver, K. G. 1995b: Porosity evaluation of seismicallyresolved Zechstein carbonate layers, Løgumkloster-1 well, Denmark. Journal of Petroleum Geology 18, 329-344.

Maver, K. G., Møller, J. J. \& Andersen, C. 1992: Inverse modelling to test seismic resolution of carbonate reservoirs. In Frias, M. (ed) Optimization of the production and utilization of hydrocarbons, 186-202. London: Graham \& Trotman.

Maver, K. G., Rasmussen, K. B., Pedersen, J. M. \& Skjellerup, P. 1994: Global seismic inversion with variable prior knowledge. Extended abstract SI3.8, Society of Exploration Geophysicists, 64th annual meeting, USA. 10241027.

Rider, M. H. 1986: The geological interpretation of well logs. 175pp. Blackie Halsted Press.

Sorgenfrei, T. \& Buch, A. 1964: Deep tests in Denmark 19351959. Danmarks Geologiske Unders $ø$ gelse III, rk 36, 146 pp.

Stemmerik, L. \& Frykman, P. 1989: Stratigraphy and sedimentology of the Zechstein carbonates of southern Jylland. Geological Survey of Denmark, Series A, 26, 32pp. 
Stemmerik, L., Frykman, P., Winther Christensen, O. \& Stentoft, N. 1987: The Zechstein carbonates of southern Jylland, Denmark. In Brooks, J. \& Glennie, K. (eds) Petroleum Geology of North West Europe, 365-374. London: Graham \& Trotman.

Stentoft, N. 1990: Diagenesis of the Zechstein Ca-2 carbonate from the Løgumkloster-1 well, Denmark. Geological Survey of Denmark, Series B, 12, 42pp.

Thomsen, E., Damtofte, K. \& Andersen, C. 1987: Hydrocarbon plays in Denmark outside the Central Trough. In Brooks, J. \& Glennie, K. (eds) Petroleum Geology of North West Europe, 375-388. London: Graham \& Trotman.

Ziegler, P. A. 1981: Evolution of sedimentary basins in North-West Europe. In Illing, L. V. \& Hobson, G. D. (eds) Petroleum geology of the continental shelf of North-West Europe, 3-39. London: Institute of Petroleum. 